\title{
Indexes
}

\section{Index of biblical writings}

\section{Old Testament (Septuagint)}

\section{Genesis}

1.26-28 186-187

$3.1966,67$

4.2585

5.185

6.984

15.6210

Exodus

$\begin{array}{lll}3.12 & 242 & \\ 3.18 & 243 & \\ 4.23 & 243 & \\ 6.12 & 62 & \\ 8.4 & 243 & \\ 10.25 & -26 & 243 \\ 32.27 & 51 & \end{array}$

Leviticus

$19.18 \quad 55$

Numbers

$25.3,6-8 \quad 241$

\section{Deuteronomy}

$$
\begin{aligned}
& 6.5 \quad 240,243 \\
& 10.12 \quad 240,245 \\
& 10.12-13 \quad 243 \\
& 14.23 \quad 244 \\
& 28.47-48 \quad 243 \\
& 30.14 \quad 246
\end{aligned}
$$

1 Kings (3 Kingdoms)

11.1-8 241

\section{Kings (4 Kingdoms)}

17.15202

\section{Maccabees}

$4.14 \quad 254$

Psalms

8.6-9 186-187

48.13, 2166,67

105.19200

$105.20 \quad 200$

Wisdom of Solomon

2.23133

Isaiah

40.6-8 11

49.6207

Epistle of Jeremiah

$6.50 \quad 202$

Daniel

$4.34 \quad 241$

4.37241

7.13-14 187

\section{New Testament}

Matthew

$19.19 \quad 55$

$22.39 \quad 55$

Mark

$12.31 \quad 55$

\section{Romans}

$1-8 \quad 179-180,204-210$

1-11 5

1.1-7 228

¿ OpenAccess. (C) 2021 Simon Dürr, published by De Gruyter. (cc) BY-NC-ND This work is licensed under the Creative Commons Attribution-NonCommercial-NoDerivatives 4.0 International License. https://doi.org/10.1515/9783110750560-012 


\section{Romans (continued)}

1.9240

$1.18 \quad 241$

1.18-21 191-196

1.18-32 157, 189-210

1.19-20 156

$1.19-21 \quad 170$

$1.20 \quad 95-96$

$1.21 \quad 173$

1.21-22 196-199

1.23-25 199-204

$1.25 \quad 240-242$

1.26-27 158, 170

$1.28 \quad 196-199$

1.29-31 145, 199

1.30-31 96

2.17-24 205

$2.18 \quad 206$

$2.19 \quad 206$

2.19-20 207

$2.23 \quad 206$

2.25-29 145

3.9208

3.21119

$3.23 \quad 208-210$

$4.9 \quad 210$

$4.11 \quad 210$

$4.17 \quad 210$

4.18-25 208-210

5.2-5 281

5.12-21 179-189

5.15-21 276

$5.17 \quad 183-188$

6.1-11 212-216

$6.4 \quad 226$

$6.11 \quad 265$

$6.12 \quad 67$

6.12-23 216-224

$6.13 \quad 119$

7.4-6 223

$7.22 \quad 112$

8.5-6 224-226

$8.9-11 \quad 225-226$

$8.17-30 \quad 226-227$

$8.19 \quad 276$

9-11 177

$9.4 \quad 242-244$

\section{Romans (continued)}

11.120

$11.36 \quad 73$

12-15 267-292

$12-16 \quad 5$

$12.1 \quad 231-232,233-263,264-265$

12.1-2 1-2, 5, 266, 272-277

$12.2 \quad 264-265$

$12.3-8 \quad 146,278-280$

$12.9 \quad 68$

$12.9-21 \quad 280-282$

$12.17 \quad 68$

$12.21 \quad 68$

$13.9 \quad 55$

13.11-14 282-285

14.1-15.13 285-291

$14.6 \quad 288$

$14.14 \quad 288$

14.17-18 289

14.19290

$14.20 \quad 290$

15.5-7 290-291

15.69

$15.16 \quad 229$

16.19275

1 Corinthians

$8.6 \quad 73$

10.23-33 288

$10.31200,288$

15.20-28 187

$15.47-49 \quad 66$

$15.48 \quad 67$

$15.5820,283$

2 Corinthians

$4 \quad 188$

$5.17 \quad 20$

$5.18 \quad 219$

$5.21 \quad 219$

Galatians

2.11-14 145 


\section{Ephesians}

\subsection{1-21 291}

3.1019

\section{Philippians}

\begin{tabular}{|c|c|}
\hline 1.27 & 245 \\
\hline 2.12 & 144 \\
\hline 3.3 & $239,244-245$ \\
\hline 3.19 & 142 \\
\hline
\end{tabular}

\section{Thessalonians}

5.1-11 282

\section{Peter}

$\begin{array}{ll}1.23 & 11 \\ 1.25 & 11 \\ 2.2 & 11 \\ 2.5 & 11\end{array}$

\section{Index of further ancient sources}

Aelian, De natura animalium 53

Aelius Herodianus, Partitiones 54

Aeschylus, Prometheus vinctus 254

Aesop, Fabulae 99

Aëtius 51, 52

- Doxographi Graeci 41, 53

Alcinous 51

- Didaskalikos 53, 58

Alexander of Aphrodisias

- In Aristotelis metaphysica commentaria 32-33, 52

- In Aristotelis topicorum libros octo commentaria 42

Antisthenes, frag. 44b 32-33

Apollonius Dyscolus, De adverbiis 54

Aristodemus 103

Ariston of Chios, frag. $374 \quad 68$

Aristophanes, Aves 93

Aristotle

- Categoriae 141

- De anima 118

- De partibus animalium 106, 114-116

- Ethica Nicomachea

$\begin{array}{ll}1.7 .9-16 & 143 \\ 1094 a & 74 \\ 1097 b & 80,81,129,143 \\ 1098 a & 82,83 \\ 1102 a & 82,120 \\ 1102 b & 83 \\ 1111 b & 83 \\ 1145 a & 119 \\ 1177 a & 6,120\end{array}$

Aristotle (continued)

- Ethica Nicomachea (continued)

1177b 6, 120

1770a 118

- Metaphysica 6, 32, 118

- Politica

$1252 a 116$

$1252 b \quad 116,117$

1253a 115, 117, 118, 119

- Protrepticus 125-127

- Rhetorica 115

- Topica 196

Arius Didymus 49

- De Philosophorum Sectis 26, 27, 29, 30

- Epitome 49, 121

Aspasius

- In ethica Nicomachea commentaria

2.26-3.2 63

4.7-11 74

4.10-11 52

17.18-29 80-81

17.29-18.2 56, 81-82, 129-130

$17.32 \quad 143$

18.1-2 30, 259

$18.2-9 \quad 83$

18.9-13 83-84

27.11-19 52

27.14-17 62

44.1-3 52

$67.1-3 \quad 74$

128.1-2 143

130.6-12 52 
Aspasius (continued)

- In ethica Nicomachea commentaria (continued)

130.11-13 197

153.7-9 52, 67, 75

Athenagoras 54

- De resurrectione 56, 76, 133

Carneades 147

Cassius Dio 49

Chrysippus $31,34-37,38-39,40,41,45-$ $46,58,78,165$

Cicero

- De finibus

$$
\begin{aligned}
& \begin{array}{l}
1.29 .11-14 \quad 237 \\
3.20-21 \quad 198 \\
5.41 \quad 131
\end{array}
\end{aligned}
$$

- De natura deorum 33, 77-78, 138

2.3147

$2.36 \quad 78$

$2.3777,78,130$

$2.38 \quad 78$

$2.39 \quad 59$

$2.64 \quad 152$

$2.160 \quad 152$

- De officiis 33

$1.2247,130-131$

$1.50 \quad 115$

1.107-116 146

- Epistulae ad Atticum 16.14.3 198

- Tusculanae disputationes

1.32130

1.69132

1.73166

5.979

Claudius Ptolemy, De judicandi facultate et animi principatu 54

Clement of Alexandria 54

- Paedagogus 55, 80

- Stromateis 55, 66, 71

Clementine literature see Pseudo-Clementines

Cleomedes 49

- Caelestia 50

Cornutus 49

- De natura deorum 50
Didymus the Doxographer 49

Dio Chrysostom

- Ad Nicomedienses (Or. 38) 86

- Borysthenitica (Or. 36) 86-89

- De fortuna ii (Or. 64) 50-51

Diogenes Laertius

- Vitae philosophorum

$2.37 \quad 237$

$7.40 \quad 60$

$\begin{array}{ll}7.41 & 41\end{array}$

$7.51 \quad 26,72,258-259$

$7.86 \quad 46$
7.87

$7.87 \quad 45,84$

$7.88 \quad 45$

$7.89 \quad 35,45-46$

$7.130 \quad 77$

$7.135 \quad 40-41$

$7.137 \quad 40$

7.138-139 39

$7.139 \quad 39$

$7.142-143 \quad 39$

$7.147 \quad 40$

$7.148 \quad 40$

$7.149 \quad 41$

9.5198

Dionysius of Halicarnassus, De compositione verborum 26

Empedocles 52

Epictetus

- Diatribai (Dissertationes)

1.4.3 139

$1.6 \quad 169-174,187,195$

1.6.2 195

1.6.9 203

1.6.12-16 171

1.6.17 172

1.6.19 172

1.6.20-21 173

1.6.23-25 174

$1.6 .40 \quad 187$

1.6.41 187

$1.6 .42 \quad 163,187$

1.9.24 167

$1.10 .10 \quad 58$

$1.12 \quad 147-151$

1.12.1-3 147 
Epictetus (continued)

- Diatribai (Dissertationes) (continued)

$1.12 .4 \quad 148$

1.12.5-6 148

1.12.7-8 148-149

$1.12 .23 \quad 148,165$

$1.166,151-168,195,248$

1.16.1 152

1.16.1-18 151-162

$1.16 .2 \quad 152$

1.16.3 152, 155

$1.16 .4 \quad 152$

1.16.5 152

1.16.6-7 154

$1.16 .8 \quad 155$

$1.16 .9 \quad 157$

1.16.10-11 158

1.16.12-14 159

1.16 .15160

1.16.16-18 161

$1.16 .19-21 \quad 162-168$

1.16.20 195

1.16.20-21 2-3, 144

1.16.21 195

1.1976

1.19 .976

$1.19 .10 \quad 76$

1.19 .1176

1.19.12 77

1.19.13 77

1.19.14 77

$2.9 \quad 139-146$

2.9.1-3 140

$2.9 .4 \quad 141$

2.9.5-7 142

2.9.8-9 143

2.9.11-12 144

2.9.13-21 145

2.9.21 145

2.9.22 145

2.10.1-4 146

$2.10 .419,140,146,279$

2.17.29 106

2.19.14 145

3.1.25-26 72

3.21.19 238

3.22188
Epictetus (continued)

- Diatribai (Dissertationes) (continued)

$3.22 .46 \quad 188$

$3.22 .47 \quad 188$

$3.22 .49 \quad 188$

$3.22 .56 \quad 237$

$3.22 .80 \quad 188$

3.23.4-5 145

$4.7 \quad 147-151$

4.7.6 $149-150$

4.7.7 150

$4.8 \quad 140$

- Discourses see Diatribai (Dissertationes) above

- Enchiridion 74

see also index no. 3 Arrian

Eudorus of Alexandria 51

Euripides

- Phoenissae 253

- Troiades 253

Eusebius, Historia ecclesiastica 1.3.4 254

Galen 52, 63

- Adhortatio ad artes addiscendas 52, 62, 63, 64

- De alimentorum facultatibus libri iii 52

- De differentia pulsuum libri iv 52

- De methodo medendi libri xiv 52

- De placitis Hippocratis et Platonis 35-37, 52, 61, 68

- De sanitate tuenda libri vi 52

- De semine libri ii 52

- De symptomatum causis libri iii 52

- De usu partium 52, 76

- In Hippocratis librum vi epidemiarum commentarii vi 52

- see also Pseudo-Galen

Genesis Rabbah $14.6 \quad 209$

Hermetic writings, Corpus Hermeticum 11

Heron, Definitiones 26

Hesiod, Opera et dies 94

Homer

- llias

$\begin{array}{ll}10.279-280 & 147 \\ 17.446-447 & 93\end{array}$ 
Iamblichus

- De vita Pythagorica 43

- Protrepticus 125-127

- see also Aristotle: Protrepticus

Irenaeus 54

- Adversus haereses 55

Isocrates, Ad Nicoclem (Or. 2) 275

Josephus, Contra Apionem 2.195132

Justin Martyr 54

- Dialogus cum Tryphone 93.3 55

Longinus see Pseudo-Longinus

Lucian, Apologia 253

Marcus Aurelius

- Meditations

2.16.1 46, 129

$3.9 \quad 47$

4.3.2 47

5.1 .1129

5.1647

$5.29 \quad 48$

$5.34 \quad 48$

7.1146

8.19150

$8.3544,48$

$8.3948,76$

9.1.1 48, 75-76

$9.9 .247,48,59$

$9.1646,48$

$10.246,47$

$10.28 \quad 48$

Maximus of Tyre, Dissertationes 61

Michael of Ephesus 33, 52

Musonius Rufus 158

- Dissertationes 203

Nemesius of Emesa, De natura hominis $31-$ $32,61,64,65,66,67-68$

Nicomachus of Gerasa, Theologoumena arithmeticae 54

Origen 54

- Contra Celsum
4.7469
4.7569
4.7870

Origen (continued)

- Contra Celsum (continued)

5.1059

- De oratione

6.173

6.274

- De principiis

3.1.2 60

3.1.2-3 73

3.1.3 72

- Fragmenta in Psalmos 1-150 56

Ovid

- Metamorphoses

1.84-86 106

2.367-380 165

Panaetius of Rhodes 33

Persius Flaccus, Satirae 132

Philo of Alexandria 51, 52

- De Abrahamo 84, 85

- De aeternitate mundi 71

- De agricultura 60

- De cherubim 25

- De confusione linguarum 59-60, 61, 86

- De congressu eruditionis gratia 28, 86

- De decalogo 60,148, 202

- De Deo 71

- De ebrietate 51

- De fuga et inventione 86

- De migratione Abrahami 44, 79

- De opificio mundi 30,66

- De plantatione 86

- De posteritate Caini 30

- De praemiis et poenis 78-79, 85

- De sacrificiis Abelis et Caini 62

- De somniis I 30, 44, 79

- De somniis II 86

- De specialibus legibus I 79, 196, 239240, 245, 246, 256

- De specialibus legibus II 44

- De vita Mosis I 12

- Legum Allegoriae I 25, 62

- Legum Allegoriae II 26,70

- Quaestiones et solutiones in Genesin I 51

- Quis rerum divinarum heres sit 61, 196 
Philo of Alexandria (continued)

- Quod deterius potiori insidari soleat 29, 44, 62, 85, 106, 196

Philodemus of Gadara 51, 52

- Herculaneum papyri 33-34

Philoxenus of Alexandria 54

Plato

- Apologia 237, 238

- Cratylus 110

- Leges 111

- Menexenus 109

- Phaedo 165, 166

- Protagoras 96, 97, 98, 119

- Respublica 84

352d-354a 143

$353 a \quad 123$

434d-441c 111

500b 113

500d 113-114

588b-589d 112, 143

589a-b 112-113

589d 113

590b 112

591c 72

- Theaetetus 51, 98, 114

- Timaeus

29d-30b 37

$30 \mathrm{~b} \quad 38$

90e-92c 109

91d 110

91e 110

92a 110

92b 110

92c 109

Pliny the Elder, Naturalis Historia $\quad 102,164$, 165

Plutarch 51, 52

- Animine an corporis affectiones sint peiores 93

- Consolatio ad Apollonium 254

- De amore prolis 42, 93, 122

- De communibus notitiis contra Stoicos 41-42, 59-60

- De Stoicorum repugnantiis 41

- De tranquillitate animi 132

- De virtute morali 34, 35, 61
Plutarch (continued)

- Marcius Coriolanus 12

- Quomodo adulator ab amico internoscatur 254

- see also Pseudo-Plutarch

Polybius, Histories 139

Porphyry, De abstinentia 165

Posidonius 31

- frag. 29, 31-32, 64, 65

Priene, inscriptions 139

Pseudo-Clementines, Homilies 53

Pseudo-Galen, De historia philosophica 41

Pseudo-Longinus, De sublimitate 131

Pseudo-Plutarch, Placita philosophorum 41, 53

Quintillian, Institutio oratoria 128

Seneca

- Epistulae morales
41.1-2 19
$41.8 \quad 128$
53.13-15 60
$120.14 \quad 131$
$121.14 \quad 128$
123.3128

Seniores Alexandrini, frag. 54

Severus latrosophista, De instrumentis 29

Sextus Empiricus

- Adversus Mathematicos

Adversos ethicos (AM 11) 52, 68

Adversos logicos 1 (AM 7) 42, 52, 118

Adversos logicos 2 (AM 8) 52, 57, 63, 72

Adversos physicos (AM 9-10) 37-38, 39, 44, 52

- Pyrrhoniae hypotyposes $\quad 42,52$

Sibylline Oracles 254

Sophocles, Antigone $\quad 99-100,101,102$

Stobaeus

- Anthologium 41, 53, 72

- Eclogae 98

- Florilegium 98

Strabo, Geographica $\quad 49-50$

Tatian 54

- Oratio ad Graecos 57

Testament of Levi $3.6 \quad 12$ 
Theognis 94

Theophrastus 53

- De sensu 95

Thucydides, Historiae 263
Xenophon, Memorabilia $\quad 37,102,103,104-$ 108

Zeno of Citium $\quad 36-37,44,45$

\section{Index of modern authors and subjects}

action nouns, and adjectives 252-255

Adam-Christ typology, and new kind of humanity 180-183

Adams, Edward 209

adjectives, and action nouns 252-255

Agamben, Giorgio 16

Alcmaeon, on humans 95-96

ancient discourse on being human, and role of reason 92-122

ancient philosophy, cultural acceptance of 137-138

animal rationality 92

Annas, Julia 18-19, 196

anthropology, ancient discourse on role of human reason $\quad 92-122$

Aristotle

- on humans as political beings 114-120

- Épyov argument paraphrased by Aspasius 80-84

Arrian, and Epictetus' teachings 135, 151

Aspasius, use of 入оүıкós language $\quad 80-84$ assimilation to God 213

Baker, Paul 14-15

baptism, and change of bodily conditions

176-177, 207, 213-214

Barclay, John M. G. $\quad$ 179, 231, 275, 277, 286, 287, 290

- on „ethics“ and „theology“ 270-272

beards, function of 158-160

being human, ancient anthropological dis-

course on 92-122

Betz, Hans D. 10, 238-239

Bird, Michael F. 268

body

- fit with reason in humans 108

- as means of sign production 185,190

- role of 108,211 body (continued)

- see also change of bodily conditions; liberation of body

body of Christ (community)

- and kingdom of God 285-291

- tasks within 278-280

Bonhöffer, Adolf $\quad 89,136,137$

Bradley, Keith 287

Bultmann, Rudolf 135, 268

Byrne, Brendan 134, 248, 256, 258, 282

change of bodily conditions, for sign production 21-22, 185, 213-214, 221-223, 246-247, 265, 285, 296

change of conditions

- through Christ event 207, 212-213

- see also change of bodily conditions

Christ event 20-23

- and Gentiles 7

- and genuine humanness 186, 188

- and human vocation 205-208, 223

- significance of 181-183, 233, 285

- see also change of conditions

Christ-followers, vocation of 216-224

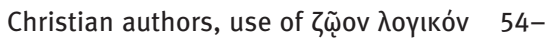
57

Cicero, as source for Stoicism 33

Clay, Jenny S. 95

communities, ideal of, fulfilling human calling 277-285

community

- concept of 5

- see also body of Christ (community)

community life 9

- and human vocation 7

- vision of 272-273

conditions, change of see change of conditions 
contemplation

- and action 75, 77-80

see also structure of human vocation

- in Aristotle 6

- and human vocation 127, 133

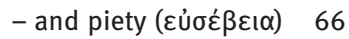

- see also $\theta \varepsilon \omega \rho i ́ \alpha$

cosmos, place and role of human beings 57-75

Cranfield, Charles E. B. $\quad$ 231, 233, 236-237, 248, 290

Cycnus son of Sthenelus, myth of 165

death

- metaphorical use 185-186, 214-215, 221

- and resurrection 7, 212, 215-216, 296 see also Christ event

Denyer, Nicholas 97

Des Places, Édouard 126

diatribe, use of term 135

Dibelius, Martin 268

Dickerman, Sherwood 0. 102

Dierauer, Urs 32, 92, 102, 120, 121

Dillon, John 137

Diogenes of Apollonia, as source for Xenophon's Socrates (Memorabilia) 102103

discourse on being human, 92-122

divine providence, and human vocation in Epictetus 147-151

divisions on scala naturae 59-75

Dobbin, Robert F. 151, 153, 155, 165, 166, $171,172,173$

Döring, Klaus 246

Dorion, Louis-André 103

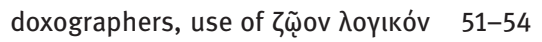

DuBois, Page 116

Dunn, James D. G. $\quad 182,183,186,187,248$, 251, 268, 269, 270, 290

Eastman, Susan G. 136

Edwards, Mark J. 156

Eijk, P. J. van der 31-32

Engberg-Pedersen, Troels 137, 161

enslavement, language of 221
Epictetus

- on divine providence and human vocation 147-151

- on human beings and genuine humanness 135-138

- as important parallel 135-136, 137

- „On Providence“ see index no. 2 Epictetus: Diatribai (Dissertationes) 1.16.1-18

- and Paul 135-138

- philosophical context 135-138

- structure of human vocation 169-174

- on 入оүıкós and human vocation 151-168

eschatology, and human vocation 282-285

Esler, Philip F. 268

„ethics“ and „theology“, integration of

- Barclay, John M. G. on 270-272

- models for 269-272

- in Romans 268-269

Evans, Christopher 10, 267

exhortation see protreptic function of language

faculties, ascending scales of 70-72

Ferguson, Everett 11

Fitzmyer, Joseph A. 186, 258

Flashar, Hellmut 115

Forschner, Maximilian 45, 78, 88, 198, 199, 247

Foucault, Michel 14

Früchtel, Ursula 60

function (हैpyov)

- of human beings $\quad 80-84$

- see also हैpyov

Furnish, Victor P. 197

Garnsey, Peter 116

Gathercole, Simon 145, 149

genuine humanness

- through Christ 212-216

- corruption of 189-210

- defined by Epictetus 139-146

- expressed in source texts 122-133

- and human vocation 17-18

- and Jewish traditions 199-204

- meaning of 84-86

- role of Spirit $\quad 224-226$ 
genuine humanness (continued)

- Romans 12.1-2 as exhortation to 230266

- Romans on 179-189

- signs of 280-282

- use of term 15-22

- see also human vocation

Gill, Christopher 148, 149

Goodrich, John K. 278

Goranson Jacob, Haley 186

Greco-Roman anthropological discourse, on human reason 92-122

Greco-Roman context, of Paul's writings 178

Greek terms, for reason language 1

Griffith, Mark 100

Gupta, Nijay K. 255

Hahn, Scott $\quad 267,268$

hair growth, function of 158-160

Halperin, D. M. 158

Hard, Robin $\quad 138,140,152,154,161,164$, 167, 169, 171, 249

Harding, Sarah 185

Heinemann, Isaak 131, 174, 192

- Die Lehre von der Zweckbestimmung des Menschen 122-125

- human vocation, language for 122-133

Hengel, Martin 149

Hesiod, contrasting humans and animals 94-95

Hiebert, David Edmond 255

holy Spirit, role for genuine humanness 224-226

Hooker, Morna D. 199, 200

hope, in Philo, De praemiis et poenis 78

Horn, Christoph 92, 115

Hügli, Anton 93, 99, 102

human behaviour, and Christ event 212-216

human beings

- contemplation and action $\quad 77-80$

- contrasted with gods 92-94

- defined by Epictetus 139-146

- „fashioned“ for a purpose 75-77

- as „mortal rational animals“ 3, 75-84, 139-140

- place and role in cosmos 57-75, 122-133 human beings (continued)

- vocation of 75-84

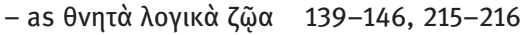

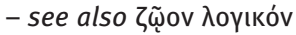

human body see body

human calling see human vocation

human proprium, corruption of 196-199

human reason

- ancient vs. modern views 3

- Greco-Roman anthropological discourse on $\quad 92-122$

- Stoics on 120-121

human vocation $122-133$

- and community 277-285

- conclusion and implications 204-210

- cosmic horizon of 224-226

- defined by Epictetus 139-146

- and eschatology 282-285

- and genuine humanness 17-18

- and Isaak Heinemann 122-133

- language for 122-133

- Paul on 293-298

- and Paul's theology and ethics 7, 274275, 298

- and reason language 7

- in Romans 1.18-21 and in Epictetus 193196

- in Romans 7

- structure of 169-174, 193-196

see also structure of human vocation

- use of term 15-22

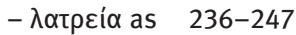

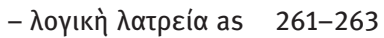

- see also genuine humanness

humanness see genuine humanness

Huttunen, Niko 136, 145, 149

idol polemics 201-202

Imbert, Claude 259

immortality of soul $165-166$

inner „powers“ see faculties

inscriptions see $\lambda$ оүıкós: epigraphical evidence

integrated existence in Romans $12-15$, vision of 267-292

interpretative terms $15-22$

Inwood, Brad 115, 259 
Jewett, Robert $\quad 1,248,273,283,290$

Jewish context, of Paul's writings 178-179

Jewish idol polemics 201-202

Jewish traditions, on genuine humanness

199-204

Käsemann, Ernst $\quad 133,183,194,268,274$, 276

Keener, Craig S. $\quad 256,264,278,279$

Kerferd, George 259

kingdom of God, and united community of those in Christ 285-291

lameness, Epictetus's reference to 165

Landmann, Michael 92, 97, 99, 102, 114

language, for human vocation 122-133

Latin terms, for reason language $1,78,128$

Lausberg, Heinrich 197

liberation of body

- and sign production 211-212, 214, 233,

277, 285

- see also baptism

living sacrifice, bodies presented as 233235

logical divisions on scala naturae 59-75

Long, Anthony A. 45, 135, 137, 169, 172,

174, 237, 259

Longenecker, Richard N. 255

Luther, Martin 181

Mansfeld, Jaap 37

Matera, Frank J. 267, 269

McCartney, Dan G. 27

methodological approaches

- evaluating qualitative parallels 13-14, 24, 30, 293-294

- semantic 13-14, 293

- traditionsgeschichtlich 2, 3, 13-14, 293

Michel, Otto 179, 183, 206

Miller, Colin D. $\quad 18,185$

mission, missional, definition of 20

missional existence in Romans 12-15, vision of 267-292

Moore, Stephen D. 92

Müller, Jörn $\quad 108,111,113$ mundum contemplandum and imitandum (Cicero) 77-78

- see also sign production; structure of human vocation

Nanos, Mark D. 286

Nasrallah, Laura Salah 221, 287

natural slavery, Aristotle on 116

natural theology $132,176,195,199$

Nemesius of Emesa, and Posidonius 64

new creation, producing signs of 226-227

new identity 211-224

New Perspective on Paul 20-21

New Testament writings, and ancient philosophers 138, 156, 276

Niehoff, Maren R. 51, 92, 134, 209

nightingales, known for singing 164

Norden, Eduard 156

nouns, and adjectives 252-255

Novenson, Matthew V. 177

Oldfather, William Abbott $\quad 169,172$

Osborn, Eric F. 156

paraenesis

- in Romans 12-15 268

- vision of community life 272-273

participation in Christ 212-213, 269

Paul (apostle)

- belief in new way of being human 7

- and Epictetus 8,135-138

- Greco-Roman and Jewish contexts 178179

- on human vocation 293-298

- New Perspective on 20-21

- sense of vocation 227-229

Pistelli, Ermenegildo 127

Plato, on humans 108-114

Posidonius, and Nemesius of Emesa 64

powers see faculties

Protagoras

- on humans 96-99

- see also index no. 2 Plato: Protagoras

protreptic function of language

- in definition of human beings 25, 64

- in Epictetus $163,168,171$ 
protreptic function of language (continued)

- in Galen 62

- and role of human beings 9

- in Romans 12.1-2 127, 136, 247, 264, 272, 292

- in Stoics 120, 138

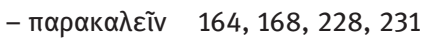

providence see divine providence

Pythagoras, as spectator of nature 79

Rackham, Harris 82

Rapp, Christof 115

ratio, in Latin texts 128

rationalis, in Latin texts 128

reason language

- Greek terms for 1

- Latin terms for 1, 78

- main approaches to $10-15$

- Paul's use of 1-3

- used in ancient texts in wider sense 92-

122

- see also 入оүıко́ৎ: in Romans 12.1

Reasoner, Mark 286

Reichert, Angelika 2, 10, 12-13, 223, 231, 232, 234, 235, 240, 273, 280, 286

Reitzenstein, Richard 251, 258

religion

- vs. reason 2

- use of term 20

resurrection see death: and resurrection

Romans 12.1-2

- function of 272-277

- links with Romans $1 \quad$ 190-191, 296

- links with Romans 6 216, 233, 235

Romans, on genuine humanness 179-189

Rowe, C. Kavin 135, 138

Runge, Steven E. 15

Runia, David T. 51

Rüpke, Jörg 223

salvation, in Romans 177-178

Sanders, E. P. $\quad 181,212$

Sandmel, Samuel 138

Saunders, Trevor J. 115, 118

scala naturae

- animals placed on 109

- humans placed on 59-75, 166
Schmithals, Walter 286

Schnelle, Udo 1, 136, 137, 267, 269, 277

Schumacher, Thomas 279

Scott, Ian W. 10-11, 13, 24-30, 142, 232, 246, 260, 262, 263, 293

Sedley, David 45, 147

Seidensticker, Philipp 231, 267

Seiler, Hansjakob 93

Seneca, on human rational nature 128

sexual behaviour 170, 190, 203, 241

sexual relations 158-159

Sharples, Robert William 31-32

sign production

- contemplation of cosmos 77

- negative 217

- in Romans 12.1b 233-235

- and structure of human vocation 167,169 , 205, 291

- use of term 15-22, 184-185

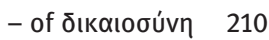

- see also structure of human vocation

$\sin$

- and powers 185

- and sign production 185

slavery 222-223

- see also enslavement; natural slavery

Smith, Nicolas D. 116

Socrates

- in Epictetus 147-148, 167

- in Plato, Apologia 237-238

- see also Xenophon

Sophocles, on humans 99-102

Sorabji, Richard 37, 92, 136

soul, immortality of $\quad 165-166$

spectators, human beings as $79,132,133$, 172

Spirit, holy, role for genuine humanness 224-226

Sterling, Gregory E. 51

Stern, Menahem 149

Stoics

- on human reason 120-121

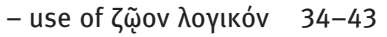

Stowers, Stanley K. 5, 141, 176, 286

Strack, Wolfram 12 
structure of human vocation

- as contemplation and action, in ancient discourse 77-80

- in Epictetus 169-174, 193-194

- mundum contemplandum and imitandum (Cicero) 77-78

- in Paul 193-196

- as sign production 193-196

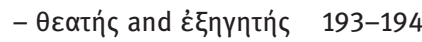

swans, approaching death 165

Theiler, Willy 31, 102-103

Theobald, Michael 179

„theology“ and „ethics“, integration of, in Romans 9, 268-269

Thiessen, Matthew 205-206

Thompson, James W. 268, 269, 276

Thorsteinsson, Runar M. 232, 251, 261, 280

van Kooten, George H. 195, 197

Vegge, Tor 89

vocation

- of Christ-followers, as sign production 216-224

- levels of, in Romans 205-208, 216-220

- Paul's sense of 227-229

- of rational animals 75-84

- service to God as 236-247

- see also human vocation

Vollenweider, Samuel 135, 149

Walter, Nikolaus 10

Wenschkewitz, Hans 5

Whitaker, George Herbert 85

Wilamowitz-Moellendorf, Ulrich von 136

Wilckens, Ulrich 12

Wolter, Michael $164,180,181,183,220$, 221, 222, 231, 232, 234, 267, 268, 286

- on Epictetus 1.16.20 and Rom 12.1 249251

- on „ethos“ and „identity“ 18, 19, 269270

- on Rom 6.4226

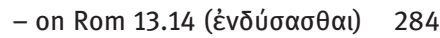

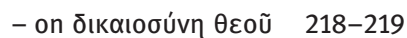

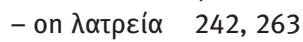

Wright, N. T. $178,202,206,208,209,212$, 219, 255, 261, 266, 276

Xenophon, on human body and mind $102-$ 108

Zahn, Theodor 136

Zuntz, Günther 126

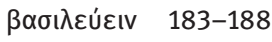

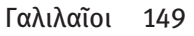

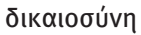

- levels of vocation $\quad 216-220$

- sign production for 216-224

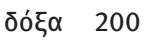

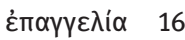

- as human vocation $\quad 139-140$

$\dot{\varepsilon} \pi \varepsilon \xi \dot{\varepsilon} \rho \chi \varepsilon \sigma \theta \alpha \mathrm{l} \quad 160$

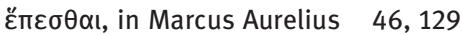

हैpyov 157, 254

- in Epictetus $1.16 \quad$ 162-168

- as function argument 143-144

- of human beings $\quad 80-84$

- used by Aspasius $80-84$

- used by Paul 228, 248, 290

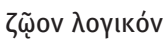

- corpus-assisted investigation of phrase 30-57

- early Stoic use of phrase 34-43

- genuine humanness of human beings 84-86

- gods and human beings as, in Stoic thought 43-48

- human beings, vocation of 75-84

- human beings as 30-89

- place of human beings in cosmos $\quad 59-75$

- pre-Pauline use of phrase 33-34

- used before first century BC 49-51

- used from first century BC onwards 51-54

- used in second century AD 54-57

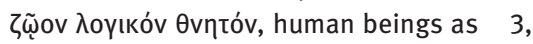
75, 84, 139-146, 215-216

$\theta \varepsilon \alpha \dot{\sigma} \sigma \alpha \theta \alpha \mathrm{l} \quad 80,127,174$

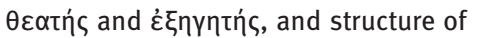
human vocation 193-194 
$\theta \varepsilon \omega \rho i ́ \alpha$

- in Epictetus 173

- and structure of human vocation 77

- vocation of human beings 131

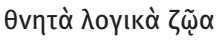

- human beings as 139-146

- as „mortal rational animals“ 3

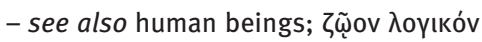
Өvitóv

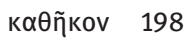

к $\alpha \lambda \varepsilon \tilde{v} \mathrm{\sigma}$

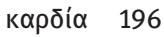

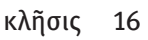

$\lambda \alpha \tau \rho \varepsilon i \alpha \quad 11$

- in combination with 入оүıкós 251-263

- conclusion for Paul's use in Romans 246247

- indicating vocation

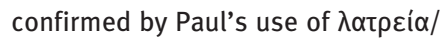

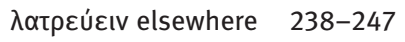
in Plato, Apologia 237-238

- in Romans 12.1c 236-247

$\lambda \alpha \tau \rho \varepsilon u ́ \varepsilon ı$ see $\lambda \alpha \tau \rho \varepsilon i ́ \alpha$ : indicating a vocation

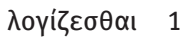

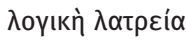

- as human vocation 261-263

- Ian W. Scott on 29-30

入оүıкóv, and voũs 196

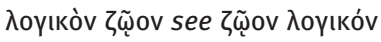

入оүıко́s

- in combination with $\lambda \alpha \tau \rho \varepsilon i \alpha \quad 251-263$

- epigraphical evidence 27-28

- example in Diogenes Laertius 258-259

- and human vocation in Epictetus 151-168

- in Latin texts 128

- in Romans 12.1 1, 10-15, 247-259

- semantics of 24-30

- used by Aspasius 80-84

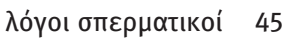

入óyos

- in Latin texts 128

- as reason and speech $35,63,115,118$

- used by Diogenes Laertius 46

- and voũs 196

voũ (lexeme family)

- in Aristotle, Ethica Nicomachea 119-120

- in Epictetus $1.16 \quad$ 155-156

- in Philo, Legum Allegoriae II 71

- in Plato, Timaeus 109

- in Romans 1.20 156, 195-196

- in Romans 12.2 1, 264-265

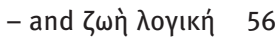

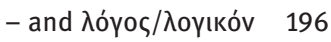

òнолоүía 198-199

$\pi \alpha \rho \alpha \kappa \alpha \lambda \varepsilon \bar{\imath} \mathrm{v}$

- in Epictetus 58, 164, 168, 228

- in Romans 12.1231

- see also protreptic function of language

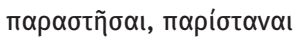

- in Romans 6.12-23 220-224

- semantics of 160

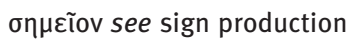

$\sigma \tilde{\omega} \mu \alpha$

- and Abraham 210

- Barclay, John M. G. on 271

- change in bodily conditions 213

- function within community 279

- human body and mind, in Xenophon 107

- and sign production 185, 216

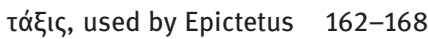

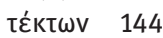

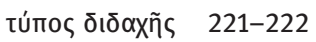

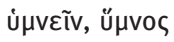

- in Epictetus 160-162, 164-168

- in Epictetus and Romans 195, 248, 250, 290-291

xópıৎ 160, 186 
